\title{
AGE-DEPENDENT CHANGES IN BLOOD COUNT OF GILTS IN LARGE-SCALE PIGGERIES
}

\author{
A. HLOUŠEK \\ Department of Farm Animal Reproduction and Surgery, University of Veterinary Science, \\ 61242 Brno
}

Received October 26, 1977

\begin{abstract}
Hloušek A.: Age-dependent Changes in Blood Count of Gilts in Large-scale Piggeries. Acta vet. Brno, 47, 1978: 7-13.

Determinations were made of the complete blood counts in 75 gilts 4 to 10 months old and of 30 to $120 \mathrm{~kg}$, divided in 5 groups according to age. The number of red blood cells was higher $(6.943,000)$ in gilts than in adult sows. The groups did not differ to a statistically significant degree. The mean level of haemoglobin was $12.5 \mathrm{~g} \%$, of hematocrit $38.9 \%$. The sedimentation rates (ESR) were 51.4 in one hour, 76.4 in $2 \mathrm{hrs}$, and 118.9 in $24 \mathrm{hrs}$. The lowest level of total blood serum proteins was determined in the first group of gilts $(6.59 \pm 0.52 \%)$. It gradually rose group by group so that in group V., the value was $16.928 \pm 2.490$. In the white blood picture, the rate and mutual proportion of neutrophils and lymphocytes was of a paramount importance. The comparatively highest number of neutrophils with segmented nuclei $(43.07 \pm 6.09 \%)$ and few lymphocytes $(48.33 \pm 7.24 \%)$ occurred in the youngest group I., while $37.57 \pm 3.15 \%$ of neutrophils with segmented nuclei and $55.22 \pm 3.64 \%$ lymphocytes were determined in group V.
\end{abstract}

Gilts, red blood picture, white blood picture, blood serum protein.

The blood count sensitively reflects the state of health and is affected by a number of factors. Age, nutrition, way of rearing and phase of sexual cycle are the most important among them. There are comparatively many studies concerning blood picture in sows, e. g. Kudlá č (1976), in the course of puerperium Śulc (1974), Herak et al. (1975), during pregnancy. However, data were often obtained with animals of different breed and age, reared under various conditions: Schalm (1965), Maclean (1972), Wirth (1950). In text-books and manuals, data of only general validity are quoted - Azimov, Krinicin, Popov (1958). The blood picture in Large White gilts in the entire course of their growth under conditions prevailing in large-scale piggeries has not been studied.

The insufficient knowledge on this field was the motivation of our present report.

\section{Material and Methods}

Determinations of the blood count were carried out in Large White gilts of different age and body mass, reared in windowless large-scale piggeries, fed three times a day with the standard mixture PCH 1 up to $50 \mathrm{~kg}$ and $\mathrm{KPB}$ above $50 \mathrm{~kg} \mathrm{~b}$. m. Drinking water was freely accessible.

Five groups were formed according to age and body mass of the gilts:

Group I: Gilts aged 4-4.5 months, of $30-40 \mathrm{~kg} \mathrm{~b}$. $\mathrm{m}$.

Group II: Gilts aged 5-6 months, of $40-50 \mathrm{~kg} \mathrm{~b} . \mathrm{m}$.

Group III: Gilts aged 7-8 months, of $60-80 \mathrm{~kg} \mathrm{~b} . \mathrm{m}$.

Group IV: Gilts aged 8-9 months, of $80-95 \mathrm{~kg} \mathrm{~b}$. $\mathrm{m}$.

Group V: Gilts aged 9-10 months, of $95-120 \mathrm{~kg} \mathrm{~b}$. $\mathrm{m}$. 


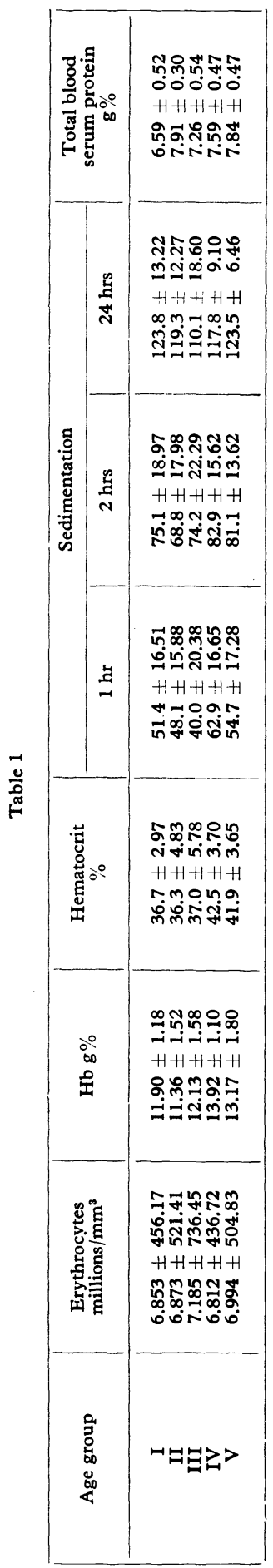

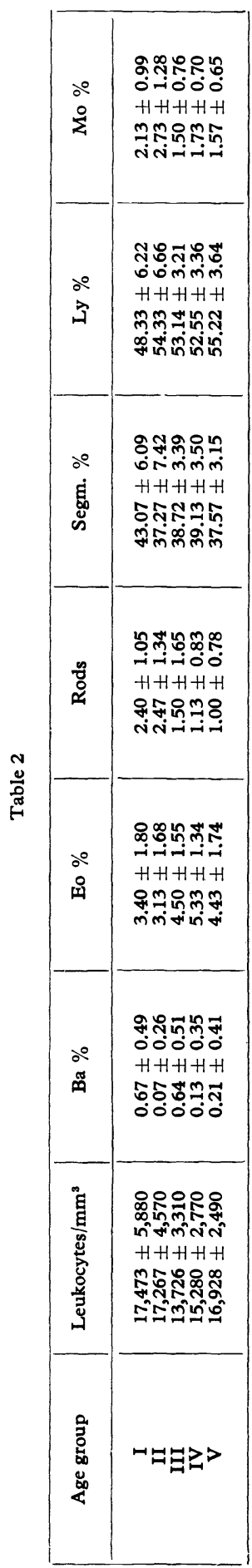

Blood samples from vena cava cranialis in group $I$, and from and ear vein punctured by a scalpel in larger animals, were collected into tubes containing evaporation residue of Wintrobe's solution. Blood smears for staining were prepared simultaneously.

The number of red and white blood cells was determined in the usual way, the white blood picture was evaluated from 400 leucocytes in smears stained by MayGrünwald's, Giemsa-Romanowki's or Pappenheim's method. Haemoglobin was determined photocolorimetrically using Drapkin's solution (Hořejší et al. 1964). Hematocrit values were ascertained by centrifugation the blood samples in Wintrobe's capillary tubes, sedimentation was performed under the angle of $45^{\circ}$ in Fahrens-Westergreen's equipment. Total proteins of the blood serum were determined by Biuret's reaction (Hořejší 1964; Hořejší 1970).

Mean values and standard deviations were calculated, and, Student's $t$-test was used to evaluate statistical differences from a group of adult sows.

\section{Results}

Erythrocytes: Up to $60-80$ $\mathrm{kg} \mathrm{b} . \mathrm{m}$., the number of red blood cells rose slightly to the maximum of $7.185,000 \pm 736,450 / \mathrm{mm}^{3}$, then decreased moderately again. Compared with sows, the number of erythrocytes was higher in all groups of gilts. The differences between groups were small and without statistical significance.

Haemoglobin: The two lowest body mass categories showed the lowest level of haemoglobin: $11.90 \pm 1.18$ and $11.36 \pm 1.52 \mathrm{~g} \%$, respectively. The haemoglobin level rose with growing age and body mass of animals, as can be seen from Table 1. The statistical significance was $P<0.05$ for the difference between groups I. and V., $P<0.01$ for the difference between groups II. and V. The differences between groups III. and IV., and IV. and V. were non-significant. 
Hematocrit: The lowest values found in group II. ( $36.3 \pm 4.83)$ were followed by an increase to highest values of $42.5 \pm 3.7$ determined in gilts of $80-100 \mathrm{~kg} \mathrm{~b}$. $\mathrm{m}$. The differences between groups I. and V., and II. and V. were highly significant $(P<0.01)$, between groups III. and V. significant $(P<0.05)$, between groups IV. and V. non-significant.

Sedimentation, read after one, two and 24 hours, showed rather irregular variations in different groups.

After one hour, its value was 51.4 in group I., dropped successively in groups II. and III., then increased to 62.9 in group IV., but, dropped again in group V. with heaviest animals. Between the groups I.-V., II.-V., and IV.-V. no significant differences were established; between the groups III. - V. $P<0.05$ was found.

After two hours, sedimentation showed alternating values. Here only the difference between groups II. and V. was significant $(P<0.05)$.

After 24 hours, the highest sedimentation of $123.8 \pm 13.22$ was observed in groups I. and V., the lowest of $110.1 \pm 18.6$ in group III. With each reading, the difference between groups III. and $V$. was statistically significant, the rest non-significant.

\section{Total blood serum protein}

In group I., the level of total protein was $6.59 \pm 0.52 \mathrm{~g} \%$. The rest of groups showed higher values: $7.91 \pm 0.30 \mathrm{~g} \%$ in group II., $7.26 \pm 0.54 \mathrm{~g} \%$ in group III., $7.59 \pm 0.47 \mathrm{~g} \%$ in group IV., and $7.84 \pm 0.47 \mathrm{~g} \%$ in group V. The differences were highly significant between groups I. and V., and III. and V., the rest was non-significant.

\section{White blood count}

The largest number of white blood cells was determined in the group of younggest gilts $(17,473 \pm 5,883)$, the lowest number in the medium group III. $(13,726 \pm$ $\pm 3,307)$. Then it increased to $16,928 \pm 2,585$ in group V. Only the difference

Table 1 a

Statistical evaluation of the complete red blood count in gilts

\begin{tabular}{|c|c|c|c|c|}
\hline \multirow{2}{*}{ Parameter } & \multicolumn{4}{|c|}{ Comparison between groups } \\
\hline & $\mathbf{I}-\mathbf{V}$ & $\mathrm{II}-\mathrm{V}$ & III - V & IV $-\mathrm{V}$ \\
\hline Erythrocytes & $\begin{array}{l}\text { increase } \\
\text { nonsignificant }\end{array}$ & $\begin{array}{l}\text { increase } \\
\text { nonsignificant }\end{array}$ & $\begin{array}{l}\text { decrease } \\
\text { nonsignificant }\end{array}$ & $\begin{array}{l}\text { increase } \\
\text { nonsignificant }\end{array}$ \\
\hline Haemoglobin & $\begin{array}{l}\text { increase } \\
P<0.05\end{array}$ & $\begin{array}{l}\text { increase } \\
P<0.01\end{array}$ & $\begin{array}{l}\text { increase } \\
\text { nonsignificant }\end{array}$ & $\begin{array}{l}\text { decrease } \\
\text { nonsignificant }\end{array}$ \\
\hline Hematocrit & $\begin{array}{l}\text { increase } \\
P<0.01\end{array}$ & $\begin{array}{l}\text { increase } \\
P<0.01\end{array}$ & $\begin{array}{l}\text { increase } \\
P<0.05\end{array}$ & $\begin{array}{l}\text { decrease } \\
\text { nonsignificant }\end{array}$ \\
\hline $\begin{array}{l}\text { Sedimentation } \\
\text { after } 1 \mathrm{hr}\end{array}$ & $\begin{array}{l}\text { increase } \\
\text { nonsignificant }\end{array}$ & $\begin{array}{l}\text { increase } \\
\text { nonsignificant }\end{array}$ & $\begin{array}{l}\text { increase } \\
P<0.05\end{array}$ & $\begin{array}{l}\text { decrease } \\
\text { nonsignificant }\end{array}$ \\
\hline $\begin{array}{l}\text { Sedimentation } \\
\text { after } 2 \mathrm{hrs}\end{array}$ & $\begin{array}{l}\text { decrease } \\
\text { nonsignificant }\end{array}$ & $\begin{array}{l}\text { increase } \\
P<0.05\end{array}$ & $\begin{array}{l}\text { increase } \\
\text { nonsignificant }\end{array}$ & $\begin{array}{l}\text { decrease } \\
\text { nonsignificant }\end{array}$ \\
\hline $\begin{array}{l}\text { Sedimentation } \\
\text { after } 24 \mathrm{hrs}\end{array}$ & $\begin{array}{l}\text { decrease } \\
\text { nonsignificant }\end{array}$ & $\begin{array}{l}\text { increase } \\
\text { nonsignificant }\end{array}$ & $\begin{array}{l}\text { increase } \\
P<0.05\end{array}$ & $\begin{array}{l}\text { increase } \\
\text { nonsignificant }\end{array}$ \\
\hline $\begin{array}{l}\text { Total blood serum } \\
\text { proteins }\end{array}$ & $\begin{array}{l}\text { increase } \\
P<0.01\end{array}$ & $\begin{array}{l}\text { decrease } \\
\text { nonsignificant }\end{array}$ & $\begin{array}{l}\text { increase } \\
P<0.01\end{array}$ & $\begin{array}{l}\text { increase } \\
\text { nonsignificant }\end{array}$ \\
\hline
\end{tabular}


Table 2a

Statistical evaluation of white blood cell count in gilts

\begin{tabular}{|c|c|c|c|c|}
\hline \multirow{2}{*}{ Parameter } & \multicolumn{4}{|c|}{ Comparison between groups } \\
\hline & $I-V$ & II $-\mathrm{V}$ & III $-V$ & IV $-\mathrm{V}$ \\
\hline Lc & $\begin{array}{l}\text { decrease } \\
\text { nonsignificant }\end{array}$ & $\begin{array}{l}\text { decrease } \\
\text { nonsignificant }\end{array}$ & $\begin{array}{l}\text { increase } \\
P<0.01\end{array}$ & $\begin{array}{l}\text { increase } \\
\text { nonsignificant }\end{array}$ \\
\hline Seg. & $\begin{array}{l}\text { decrease } \\
P<0.01\end{array}$ & $\begin{array}{l}\text { increase } \\
\text { nonsignificant }\end{array}$ & $\begin{array}{l}\text { decrease } \\
\text { nonsignificant }\end{array}$ & $\begin{array}{l}\text { decrease } \\
\text { nonsignificant }\end{array}$ \\
\hline Ly & $\begin{array}{l}\text { increase } \\
P<0.01\end{array}$ & $\begin{array}{l}\text { increase } \\
\text { nonsignificant }\end{array}$ & $\begin{array}{l}\text { increase } \\
\text { nonsignificant }\end{array}$ & $\begin{array}{l}\text { increase } \\
P<0.05\end{array}$ \\
\hline Rods & $\begin{array}{l}\text { decrease } \\
P<0.0 .1\end{array}$ & $\begin{array}{l}\text { decrease } \\
P<0.01\end{array}$ & $\begin{array}{l}\text { decrease } \\
\text { nonsignificant }\end{array}$ & $\begin{array}{l}\text { decrease } \\
\text { nonsignificant }\end{array}$ \\
\hline $\mathrm{Ba}$ & $\begin{array}{l}\text { decrease } \\
P<0.05\end{array}$ & $\begin{array}{l}\text { increase } \\
\text { nonsignificant }\end{array}$ & $\begin{array}{l}\text { decrease } \\
P<0.05\end{array}$ & $\begin{array}{l}\text { increase } \\
\text { nonsignificant }\end{array}$ \\
\hline Eo & $\begin{array}{l}\text { increase } \\
\text { nonsignificant }\end{array}$ & $\begin{array}{l}\text { increase } \\
\text { nonsignificant }\end{array}$ & $\begin{array}{l}\text { decrease } \\
\text { nonsignificant }\end{array}$ & $\begin{array}{l}\text { decrease } \\
\text { nonsignificant }\end{array}$ \\
\hline Mo & $\begin{array}{l}\text { decrease } \\
\text { nonsignificant }\end{array}$ & $\begin{array}{l}\text { decrease } \\
P<0.01\end{array}$ & $\begin{array}{l}\text { increase } \\
\text { nonsignificant }\end{array}$ & $\begin{array}{l}\text { decrease } \\
\text { nonsignificant }\end{array}$ \\
\hline
\end{tabular}

between groups III. and V. was of statistical significance, the rest was non-significant. The total number of leucocytes in gilts, particularly in both youngest groups, was somewhat higher than in sows in the same farm, where the mean value was 12,680 .

In the differential white blood count, of interest was the rate of neutrophils with segmented nuclei and of lymphocytes, and, particularly the development of their mutual proportion in the course of growth of gilts. In the youngest animals, the rate of neutrophils with segmented nuclei was the highest $(43.07 \pm$ $\pm 6.09 \%$ ), and, the rate of lymphocytes the lowest $(48.33 \pm 7.24 \%)$. As soon as in group II., the proportion shifted in favour of lymphocytes. The rate of lymphocytes remained high in all groups of older gilts so that $37.37 \pm 3.15 \%$ of neutrophils with segmented nuclei and $55.22 \pm 3.64 \%$ of lymphocytes were reached in group V. For neutrophils with segmented nuclei, the difference between groups $\mathrm{I}$. and $\mathrm{V}$. was of high statistical significance, the rest was non-significant.

Neutrophil granulocytes with rod-shaped nuclei showed a decreasing tendency with growing age and body mass of gilts. Statistically highly significant were differences between groups I. and V., and II. and V.

Basophil granulocytes occurred in very low amount only. Differences between groups were statistically significant $(P<0.05$ between groups I. and V., and III. and V.) or non-significant.

Eosinophile granulocytes showed lower values in groups I. and II. and higher values in the rest of groups, as it is obvious from Table 2. Differences were highly significant between groups I. and V., and II. and V., the rest was not significant.

Monocytes: A statistically significant difference was between groups II. and V. only. The highest rate of monocytes $(2.73 \pm 1.28 \%)$ was in group II., the lowest $(1.57 \pm 0.65 \%)$ in group $\mathrm{V}$. The incidence of monocytes was generally somewhat higher in gilts than in other categories of age and body mass. 


\section{Discussion}

The comparison of the number of red blood cells in gilts and in sows in the same farm showed a more favourable situation for gilts. The mean value for all groups of gilts was $6.943,400 / \mathrm{mm}^{3}$, for sows $6.021,000 / \mathrm{mm}^{3}$. Kudláč (1976) observed even lower values around $5.000,000 / \mathrm{mm}^{3}$ in sows during puerperium.

Our results concerning haemoglobin correspond to findings in adult sows: Schalm (1965) e. g. determined a mean of $13.3 \mathrm{~g} / 100 \mathrm{ml}$, Albritton (1952) a mean of $13.8 / 100 \mathrm{ml}(10-16 \mathrm{~g})$.

Hematocrit levels were slightly lower in gilts than in sows in the same farm. Albritton (1952) quoted $40.8 \%$ as a mean, but, considered values ranging from 30 to $50 \%$ acceptable. Our findings are in agreement with results reported by Schalm (1956) who found a mean value of $38 \%(31-48 \%)$.

As for sedimentation, there was no opportunity of comparing our results with literature data for identical categories of gilts. Compared with our findings in sows in the same farm, sedimentation after one and two hours was slightly slower in gilts, while after 24 hours there was virtually no difference between gilts and sows.

The values for total blood serum proteins were identical in gilts and sows, except for group I. Our results are in agreement with data quoted for sows: Widdow son and McCance (1956), Knill et al. (1958), Haaren (1960), Miller et al. (see Maclean, 1972) conformely reported protein levels ranging from 7.5 to $8.1 \mathrm{~g}$ per $100 \mathrm{ml}$ serum.

White blood cell count: The numbers we determined were in agreement with literature data: Schalm (1965) e. g. registered 16,000 in non-pregnant sows, Holman (1956) found $14,700 \pm 4,500 / \mathrm{mm}^{3}$.

While references quoted either a moderate prevalence of neutrophils over lymphocytes (Dukes 1955) or an approximately equal number of them Kudláč (1976) our results illustrated a higher rate of lymphocytes in young gilts. This situation persisted until adulthood.

Most authors, such as Albritton (1952), Schalm (1965), Dukes (1955), Holman (1956), reported amounts of basophils up to $1 \%$. Schalm (1965), claimed a range of 0 to $1.5 \%$ in pregnant sows Kudláč (1976), values of $0.67 \pm$ $\pm 0.33 \%$ in sows during puerperium.

The rate of eosinophils corresponded in groups III. to V. to findings in sows, and, was in agreement with data registered by Holman (1956) and Schalm (1965), who quoted $4 \pm 2 \%$.

As has been pointed out by some authors, there are difficulties in distinguishing monocytes and large lymphocytes. That might be the explanation for substantially different data varying from $0.79 \%$ - Palmer (1917) (see Maclean 1972) to $9 \%-$ Schalm (1965).

\section{Změny v krevním obrazu prasniček během růstu v podmínkách velkochovu}

Zjištovali jsme morfologický obraz krve od 75 prasniček ve stáři od 4 měsíců do 10 měsíců a tělesné hmotnosti od $30 \mathrm{~kg}$ do $120 \mathrm{~kg}$, rozdělených do 5 skupin. Počty erytrocytů byly u prasniček vyšší (průměr 6,943.400) než u dospělých prasnic. Skupiny byly vyrovnané, rozdíly nebyly statisticky významné. Hladiny hemoglobinu byly průměrně $12,5 \mathrm{~g} \%$, hematokritu $38,9 \%$. Sedimentace byla 
51,4 za 1 hod., 76,4 po 2 hod. a 118,9 za 24 hod. Nejnižší hladina celkových bílkovin krevního séra byla zjištěna u I. skupiny prasniček $(6,59 \pm 0,52 \mathrm{~g} \%)$, pak dosahovala vždy hodnot vyšších (např. u V. skupiny 7,84 $\pm 0,47 \mathrm{~g} \%$ ). Nejvyšši počet bílých krvinek byl nalezen u nejmladších prasniček (17 $473 \pm 5883$ v $1 \mathrm{~mm}^{3}$ ), u V. skupiny činil $16928 \pm 2490$ ). V bílém krevním obrazu byl nejvýznamnější procentuální výskyt a vzájemný poměr neutrofilů a lymfocytů. U nejmladši I. skupiny bylo relativně nejvíce neutrofilů se segmentovaným jádrem $(43,07 \pm 6,09 \%)$ a nejméně lymfocytů $(48,33 \pm 7,24 \%)$. U V. skupiny bylo neutrofilů se segmentovaným jádrem $37,57( \pm 3,15) \%$ a lymfocytů 55,22 $( \pm 3,64) \%$.

\section{Acknowledgement}

The skilled technical cooperation of R. Svobodová and B. Studenčík is appreciated.

\section{Изменения картины крови свинок в процессе роста в условиях промышленного свиноводства}

Нами устанавливалась морфологическая картина крови 75 свинок в возрасте 4-10 месяцев, весом 30-120 кг, разделенных на 5 групп. Число эритроцитов по сравнению со взрослыми свиноматками было в случае свинок выше (в среднем 6,943.400). Группы были выравнены, разница не отличалась статистической значимостью. Уровень гемоглобина в среднем достигал 12,5 г $\%$, гематокрита $38,9 \%$. Свертываемость крови достигала 51,4 в течение 1 часа, 76,4 в течение двух часа и 118,9 в течение суток. Самый низкий уровень общих белков сыворотки крови был установлен у первой группы свинок $(6,59 \pm 0,52$ г\%), потом всегда достигал величины побольше (в случае пятой группы, например, 7,84 $\pm 0,47$ г $\%$ ). Самое большое количество белых кровяных телец было установлено у самых молодых свинок (17.473 \pm 5.883 в 1 мм $\left.^{3}\right)$, у пятой группы достигало $\left.16.928 \pm 2.490\right)$. Самым существенным в белой картине крови было наличие в процентах и взаимное соотношение нейтрофилов и лимфоцитов. У самой молодой, первой группы было установлено самое большое количество нейтрофилов с сегментированным ядром $(43,07 \pm 6,09 \%)$, минимальное количество лимфоцитов $(48,33 \pm$ $\pm 7,24 \%)$. У пятой группы количество нейтрофилов с сегментированным ядром достигало $37,57 / \pm 3,15 / \%$ и лимфоцитов $55,22 / \pm 3,64 / \%$.

\section{References}

ALBRITTON, E. C.: Standard values in blood. Philadelphia 1952.

AZIMOV, G. I. - KRINICIN, D. J. - POPOV, N. F.: Fyziológia hospodárskych zvierat. SNPL, Bratislava 1958.

DUKES, H. H.: The physiology of the domestic animals. New York 1974.

HERAK, M. - MELITA HERAK - SOJAK, Z.: Promjene količine ukupnih bjeljančevina u krvnom serumu krmača u toku graviditeta, laktacije i nakon odbijanje prasadi. Vet. Arh., 45, 1975: 49-56.

HOLMAN, H. H.: Diagnostic methods in veterinary medicine. Philadelphia 1956. 322 pp.

HOŘEJŠ́, J. - FASSATI, M. - JÍCHA, J. - KANDRÁČ, M. - MAŠEK, K. - MICHALEC, C. - SLAVÍK, K.: Základy chemického vyšetřování v lékařství. SZN, Praha 1964, 696.

HOREJŠ́, J.: Základy klinické biochemie ve vnitřním lékařství. SZN, Praha 1970. 548.

KUDLÁĆ, E.: Změny $\mathrm{v}$ krevním obraze během puerperia u prasnic českého bílého plemene chovaných na velkovýrobních podmínkách. Vet. Med., Praha, 21, 1976: 265-274. 
MACLEAN, C. W.: The haematology and serum biochemistry of the sow during the reproductive cycle. Theses. Liverpool 1972. 119 pp.

ROTH - JOSÍFKO - MALÝ - TRČKA: Statistické metody $\mathrm{v}$ experimentální medicíně. SZN, Praha 1962, 592 pp.

SCHALM, C. W.: Veterinary Haematology. Philadelphia 1965.

SULC, J.: Krevní obraz u prasnic bílého ušlechtilého plemene v průběhu březosti. Ref. na stud. věd. konf. VŠV, Brno 1974.

WIRTH, D.: Grundlagen einer klinischen Hämatologie der Haustiere. Wien u. Innsbruck 1952. 